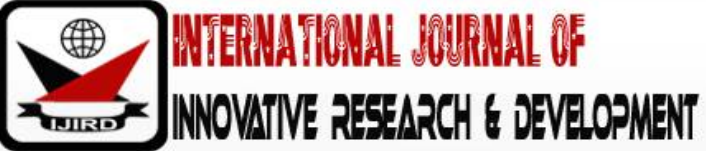

ISSN 2278-0211 (Online)

\section{Influence of Intervention Model of Local Fish Utilization to Adequacy of Energy and Protein in Children in the Coastal City of Bengkulu, Indonesia}

\author{
Meriwati Mahyuddin \\ Ph.D. Candidate, Faculty of Public Health, University of Indonesia, Indonesia \\ Diah Mulyawati Utari \\ Lecturer, Department of Nutrition of Public Health, Indonesia University, Indonesia
}

\begin{abstract}
:
The nutritional Status of toddlers is determined by food intake and infectious diseases, both factors are very much determined by the role of mother. Smart and skilled mothers are expected to meet the needs of family nutrition, especially toddlers. The optimal growth period of adaisat an early age, especially the first 2 years of life. This research aims to analyse the influence of nutrition intervention model in the form of local fish utilization education in groups of approximately 10-15 participants per group in the coastal area of Bengkulu. Location of Bengkulu City as the provincial capital is a coastal city that has not optimal the local fish utilization, one of the type of fish thyrissa sp that all year is always there and the price is relatively cheap and easy to obtain. This research is the quasi experiment with random allocation of the study area, which is the working area of the puskesmas located on the beach. The large formula of the minimal sample used is the average mean difference, so that in large need a minimum sample in each group is 28 participants with the criteria of having toddlers aged 12-18 months before the intervention, evaluation of a minimum attendance of $75 \%$ meeting. Based on exclusion or exclusion criteria, the baseline sample of the 45 participants intervention group and the 35 participants control. After 2 months of intervention, a large sample intervention group amounted to 35 and controls 32 participants. The statistical analysis used is the paired T-Test and the multivariate OF Anova analysis (MANOVA) with the help of Nutrsurvey application to process recall and Stata 16 results for data analysis. The results showed the energy adequacy rate of the baseline intervention group of 53.95\% and endline $70.40 \%$, while the baseline control group was $47.29 \%$ and endline $67.22 \%$. The nutritional intervention model affects the change in the energy adequacy rate (sign 0.007) and the protein adequacy rate (sign 0.011), as well as simultaneously affecting the average change in the energy adequacy rate and the protein adequacy rate (sign < 0.05).
\end{abstract}

Keywords: \%AKE, \%AKP, intervention, nutrition education, theory, local fish, thyrissa sp

\section{Introduction}

The direct cause of lack of nutrition is nutrient intake and infection of the disease. The main causes that produce the results are household food insecurity, inadequate health care and unhealthy environment and weak treatment for children. These three main causes are based on economic factors, political, legal, and cultural affairs, with poverty as a central role (UNICEF 2015; UNICEF, WHO, and Group 2017).

The pattern of parenting or childcare as a manifestation of the role of mother in the family in the provision of food to family members especially The toddler has a big impact on food adequacy and growth (Campbell et al. 2016; GranthamMcgregor et al. 2014; Hou 2014; Øverby, Hernes, and Haugen 2017). Unicef Indonesia study stated that the obstacles that caused the high nutritional problem of toddlers aged 6-23 months in Indonesia are inadequate knowledge and nutrition practices are not appropriate. It is specifically explained that such inappropriate knowledge and practices include the lack of exclusive and improper delivery of the accompanying meal (UNICEF 2016; UNICEF South Asia 2017).

Practice the fulfillment of toddler food is not loose from the form and source of food ingredients, one of the essential nutrients for growth is protein. The globally recognized protein source is positively influential (Kawarazuka 2017). Fish utilization in the practice of fulfillment of toddler food is very potential to be applied, given the fishery potential of the Indonesian region as a country of contentment with 17,502 fruits, coastlines of $81,000 \mathrm{~km}$ and the area of fisheries in the sea about 5.8 million km2. Mlauzi M and Mzengereza research suggests that the proportion of children's nutritional problems in fishery areas is smaller than those of non-fisheries (Mlauzi 2017).

Based on the nutritional adequacy rate (AKG) in 2013, the protein requirement per day for the age of 1-3 years is 26 grams (Kemenkes RI 2013a). Fish proteins are particularly meaningful to growth and development, in addition to the essential amino acids, the properties of which are easily digestible, compared to other animal protein sources (Kaushik 
and Seiliez 2010; Kawarazuka 2017; Mlauzi 2017). Although fish is a potential source of protein potential in Indonesia, the fact that fish consumption of Indonesian society is relatively low, year 2016 only $37.29 \mathrm{~kg} / \mathrm{capita} /$ year where the national target of $43.88 \mathrm{~kg} / \mathrm{capita} /$ year. Bengulu provincial Target of $36.09 \mathrm{~kg} / \mathrm{capita} / \mathrm{year}$, and Bengkulu City only 29.178 kg/capita/year (DKP Bengkulu province 2017; Erwina and Kurnia 2015).

\section{Methods}

\subsection{Location and Study Population}

This research is done in the work area of Puskesmas located in the coastal areas of the city of Bengkulu which most of its working area near the beach lips. Respondents to this study were mothers with toddlers aged $>12-24$ months. At the start of intervention children aged 12-18 months.

Inclusion criteria:

- Recorded in Posyandu in selected puskesmas work area

- Settled according to local government registration

- Has write-reading ability (literacy)

- Attendance during intervention $>75 \%$ of meetings

Exclusion criteria:

- Toddlers suffer from congenital abnormalities

- Do not sign informed consent Research

\subsection{Design Study}

This study was conducted through quasi-experimental research through random allocation as shown below

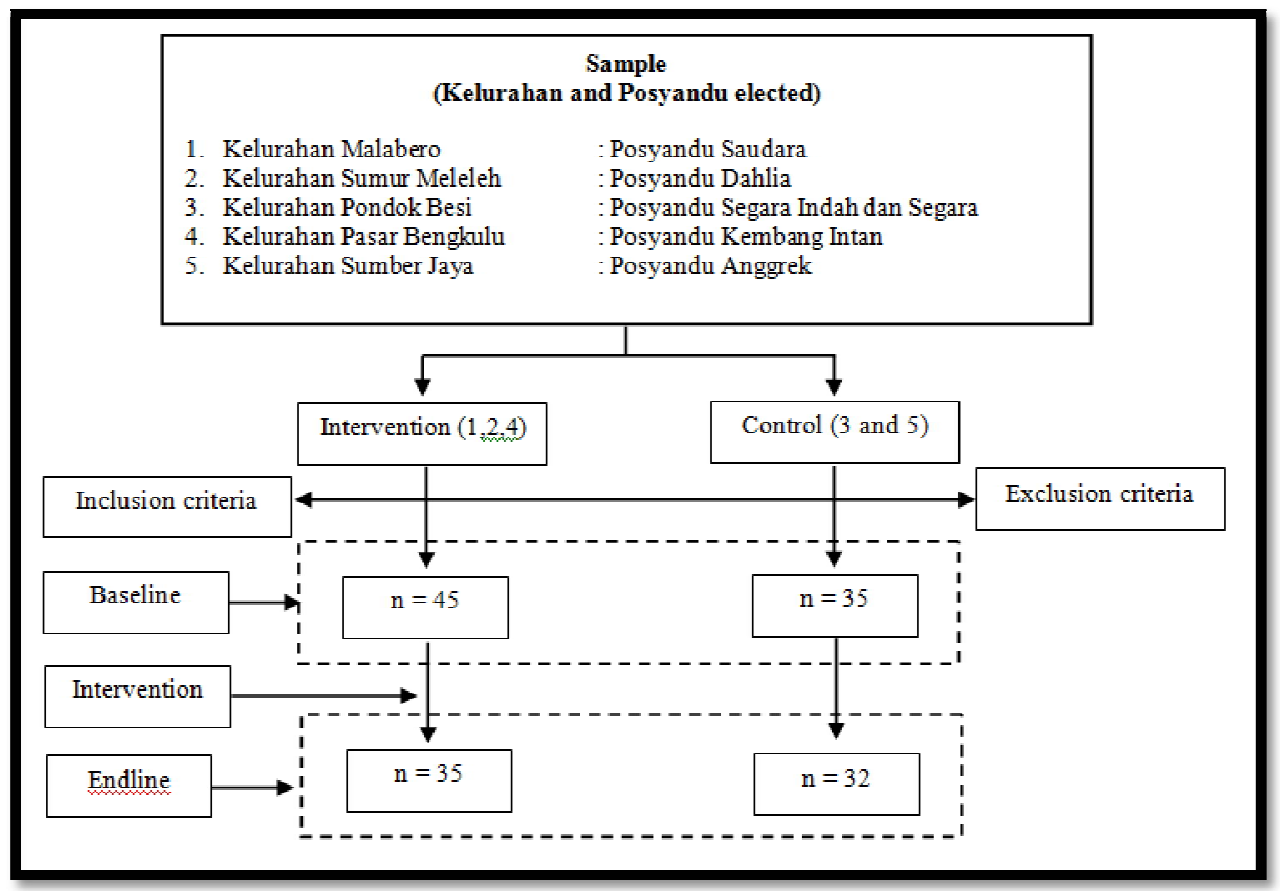

Figure 1: Flow Chart for Sample Determination and Intervention Design

At the end of the study was acquired respondents of each group as many as 35 groups of respondents in the intervention group and the 32 respondents control group. The form of intervention given in the form of nutritional education consisting of 8 meetings with material growth concept, child nutrition status, basic concept of nutrition and utilization of local fish. Interventions use simulated methods and demonstrations with media leaflets, flipcharts, stationery, materials and practice equipment tailored sub-materials.

\subsection{Data Collection}

Measurement of protein adequacy using the 24-hour recall method is compared to the standard adequacy of nutritional substances recommended by the Ministry of Health RI (Kemenkes RI 2013b).

\subsection{Data Analysis}

The data is processed with the help of Nutri Survey and Stata 16 which are analyzed according to the data properties and the appropriate statistical test techniques, namely Paired t-test, and MANOVA.

\subsection{Ethical Clearance}

This research has got the ethical approval of the Commission ethics Faculty of Public Health University of Indonesia number: 697/UN2. F10/PPM. 00.02/2018. 


\section{Results and Discussion}

Based on the results of interviews to the subject of research, obtained the following characteristics:

\begin{tabular}{|c|c|c|c|c|}
\hline \multirow{2}{*}{\begin{tabular}{c} 
Child characteristics \\
\cline { 2 - 5 }
\end{tabular}} & \multicolumn{2}{|c|}{ Intervention $(\mathrm{n}=35)$} & \multicolumn{2}{c|}{ Control $(\mathrm{n}=32)$} \\
\hline Gender & & & Amount & $\%$ \\
\hline Male & 19 & 54.29 & 17 & 53.12 \\
\hline Women & 16 & 45.71 & 15 & 46.88 \\
\hline Age Group of Children & & & & \\
\hline $12-14$ months & 20 & 57.14 & 14 & 43.75 \\
\hline $15-16$ months & 6 & 17.14 & 10 & 31.25 \\
\hline $17-18$ months & 9 & 25.71 & 8 & 25 \\
\hline
\end{tabular}

Table 1: Child characteristics

Source: Research Data, 2019

Table 1 shows that the child's gender in the control group and the practice of male proportions is much more than females. Age group proportions show that ages 12-14 months in both groups (control, education practices) are more than other age groups.

\begin{tabular}{|c|c|c|c|c|}
\hline \multirow{2}{*}{$\begin{array}{c}\text { Characteristics of } \\
\text { Mother }\end{array}$} & \multicolumn{2}{|c|}{ Intervention $(\mathrm{n}=35)$} & \multicolumn{2}{|c|}{ Control $(n=32)$} \\
\hline & Amount & $\%$ & Amount & $\%$ \\
\hline \multicolumn{5}{|l|}{ Mother age group } \\
\hline 20-35 years & 28 & 84.38 & 27 & 80 \\
\hline$>35$ years & 7 & 15.62 & 5 & 20 \\
\hline \multicolumn{5}{|l|}{ Mother's Education } \\
\hline Low & 11 & 40.62 & 13 & 31.43 \\
\hline Intermediate & 22 & 50 & 16 & 62.86 \\
\hline High & 2 & 9.38 & 3 & 5.71 \\
\hline \multicolumn{5}{|l|}{ Mother's work } \\
\hline Work & 5 & 9.38 & 3 & 14.29 \\
\hline Not working & 30 & 90.62 & 29 & 85.71 \\
\hline
\end{tabular}

Table 2 shows that the mother age group is 20-35 years old in both groups (controls and interventions) more than any other age group. The proportion of maternal education is largely intermediate category as well as in the intervention group, as well as most mothers do not work formally.

\begin{tabular}{|c|c|c|c|c|c|c|}
\hline \multirow{2}{*}{ Dependent } & \multicolumn{3}{|c|}{ Intervention } & \multicolumn{3}{c|}{ Control } \\
\cline { 2 - 7 } & Baseline & Endline & PValue $_{\text {Vaseline }}$ & Endline & P $_{\text {Value }}$ \\
\hline AKE (\%) & $53.95 \pm 22.01$ & $70.40 \pm 24.38$ & 0.001 & $47.29 \pm 17.81$ & $67.22 \pm 27.47$ & $0.000^{*}$ \\
\hline AKP (\%) & $91.02 \pm 38.45$ & $122.54 \pm 43.65$ & 0 & $84.83 \pm 37.56$ & $120.63 \pm 53.72$ & $0.000^{*}$ \\
\hline
\end{tabular}

Table 3: Number of Energy Adequacy and Protein

Source: Research Data, 2019

*The Level of Significance 0.05

Table 3 shows that the average percentage of energy and protein adequacy numbers in both groups (intervention and control) endline is greater than the baseline. The average percentage of energy and protein adequacy rates at the baseline and endline levels were found in the intervention group, meaning the average difference in the adequacy of energy and protein figures between the baseline and the endline.

\begin{tabular}{|c|c|c|c|c|c|c|}
\hline \multicolumn{2}{|c|}{ Variable } & Intervention & Control & \multirow[t]{2}{*}{$\mathbf{P}_{\text {Value }}$} & \multirow{2}{*}{$\begin{array}{c}\mathbf{R}^{2} \\
\text { Squared }\end{array}$} & \multirow[t]{2}{*}{$\mathbf{P}_{\text {Value }}$} \\
\hline Independent & Dependent & $(N=35)$ & $(N=33)$ & & & \\
\hline \multirow{2}{*}{$\begin{array}{c}\text { Model } \\
\text { intervention }\end{array}$} & AKE changes & $16.66 \pm 27.29$ & $9.94 \pm 25.35$ & 07 & 78 & \multirow{2}{*}{$\begin{array}{c}< \\
0.050\end{array}$} \\
\hline & AKP changes & $31.52 \pm 43.42$ & $25.80 \pm 43.02$ & 0.011 & 69 & \\
\hline
\end{tabular}

Table 4: Effects of Intervention Model on Changes in Energy Adequacy and Protein

Source: Research Data, 2019

*The Level Of Significance 0.05

Table 4 shows that there is an influence of the model of nutritional intervention on the change in energy adequacy rate and protein, the influence of the intervention model of the AKE change is greater than the AKP. This nutritional 
intervention Model also simultaneously affects the average change in energy adequacy figures and proteins according to all the criteria (Pillai's Trace, Wilks'lambda, Hotelling's Trace, Roy's Largest Root (sign < 0.05)

A balanced pattern of feeding at an early age will affect the appetite of the next child, so that the introduction of food in this period has become very important. As known that nutritional problems are determined by the intake and factors of disease (Unicef South Asia 2017; Unicef, WHO, and Group 2017). A good intake can cause a child to easily get infected with an infectious disease, while a child who has suffered an infection clasp affects his or her fifth ability to food. If this intake disorder runs for a long time, then the child will be slow to grow. Some studies have shown a meaningful link between the intake of food in a group, such as ingestion of consumption with the status of Anthropometry in children (Kam et al. 2016; Ramakrishnan, Nguyen, and Martorell 2018)

Nutrition Education is one of the health efforts, individually as well as a group can help individuals in regulating dietary patterns through increased awareness, motivation, facilitating the ability to take action, and improve environmental support (Contento 2007). Nutrition Education is one of the health efforts, individually as well as a group can help individuals in regulating dietary patterns through increased awareness, motivation, facilitating the ability to take action, and improve environmental support(Bullerwell et al. 2016).

Nutritional education content includes food and nutrition with personal health, such as the relationship between diet and health, healthy and balanced food recommendations, How to get the best nutrition, food safety, breastfeeding, how to get children to eat healthier, breakfast, eating balance and physical activity, addressing chronic disease-related diets (Contento, 2007). Content of fish utilization on this model of intervention is very well done, besides as food for intelligence, the dish will make a high donation on body tissues especially in children. Fish protein absorption is higher than beef, chicken, etc. This is due to the fish's meat properties that have protein fibers shorter than those of beef or chicken protein fibers. So that fish and product results are very beneficial for individuals who have digestive difficulties. The vitamins that exist in the fish are also various, namely Vitamin A, D, Thiamin, Riboflavin, and Niacin. Fish also contain minerals that are more or less the same as the minerals that exist in milk such as calcium (Kawarazuka 2017; Kristinsson and Rasco 2000; Lovell 1998).

The average baseline energy adequacy rate of research subjects is still low $(<60 \%$. 00$)$. Although the endline stage increases, but the increase has not reached $80 \%$ as the limitation is quite good or quite fulfilled. Energy function is as a power substance, a child who is experiencing energy deficiency can cause weight loss, even in a long time the impact on the body length or height with the term stunting (Htet et al. 2019; WHO 2014) and the low weight (underweight).

The fulfillment of the baseline and endline protein adequacy figures has $>80 \%$ with the largest average in the intervention group. Proteins according to its function are forming and building body tissues (Gibson 1990; Ministry of Health RI et al. 2019). Sehigga the fulfillment of protein adequacy figures must be fulfilled in order to optimal body growth, especially fish proteins that are undoubtedly the benefits and effects on children's Health (Widodo et al. 2015; Widodo DKK 2015). The Energy and nutrients required by each age are strictly determined gender and age. Based on the average nutritional adequacy rate recommended for children, especially macro nutrients for children aged 1-3 years with a height of 91 cm, weight loss $13 \mathrm{~kg}$, then adequacy of energy $1125 \mathrm{kcal}$ and 26 gram protein. The adequacy of energy and protein is said to be good if > 80\% (Kemenkes RI 2013b; Ministry of Health RI 2014).

\section{Conclusions and Recommended}

There are influences of the model of nutritional intervention on the change in energy adequacy rate and protein, where the influence of model intervention on changes in \%AKE is greater than \%AKP. This nutritional intervention Model also simultaneously affects the Second amendment of the average adequacy of energy and protein figures. So, it is necessary to develop a nutritional education program aimed to improve the skills of mothers in meeting the needs of toddlers, to improve the nutritional status of children. Good energy and Protein efficiency in children can impact normal growth and health. Children who grow normal and healthy certainly have high productivity for the time of the nations.

\section{References}

i. Arora, Chandralekha. 2009. Child Nutrition. ABD Piblisher.

ii. Brown, Judith. 2011. Nutrition Through The Life Cycle. Fourth Edi. Wadsworth Cengage Learning.

iii. Bullerwell, Christina N., Stephanie A. Collins, Santosh P. Lall, and Derek M. Anderson. 2016. "Growth Performance, Proximate and Histological Analysis of Rainbow Trout Fed Diets Containing Camelina Sativa Seeds, Meal (High-Oil and Solvent-Extracted) and Oil." Aquaculture 452: 342-50. http://dx.doi.org/10.1016/j.aquaculture.2015.11.008.

iv. Campbell, Rebecca K. et al. 2016. "Effect of Complementary Food Supplementation on Breastfeeding and Home Diet in Rural Bangladeshi Children." American Journal of Clinical Nutrition 104(5): 1450-58.

v. Contento, Isobel R. 2007. Nutrition Education: Linking Research, Theory, and Practice.

vi. DKP Propinsi Bengkulu. 2017. Konsumsi Ikan Di Propinsi Bengkulu.

vii. Erwina, Yuyun, and Rahmat Kurnia. 2015. "Status Keberlanjutan Sumber Daya Perikanan Di Perairan Bengkulu."

viii. Gibson, Rosalind S. 1990. Principles of Nutritional Assessment.

ix. Grantham-Mcgregor, Sally M., Lia C.H. Fernald, Rose M.C. Kagawa, and Susan Walker. 2014. "Effects of Integrated Child Development and Nutrition Interventions on Child Development and Nutritional Status." Annals of the New York Academy of Sciences 1308(1): 11-32.

x. Hou, Su-I. 2014. Health promotion practice Health Education: Theoretical Concepts, Effective Strategies and Core Competencies. http://www.ncbi.nlm.nih.gov/pubmed/24948598. 
xi. Htet, Min Kyaw et al. 2019. "Factors Associated with Stunting of Under Five-Year Children: Findings from Panel Surveys in Mountains, Dry Zone and Delta Regions of Rural Myanmar (2016-17) (P04-039-19)." Current Developments in Nutrition 3(Supplement_1): 207-10.

xii. Kam, Saskia Van Der, Nuria Salse-ubach, Stephanie Roll, and Todd Swarthout. 2016. "Effect of Short-Term Supplementation with Ready-to-Use Therapeutic Food or Micronutrients for Children after Illness for Prevention of Malnutrition : A Randomised Controlled Trial in Nigeria." : 1-26.

xiii. Kaushik, Sadasivam J., and Iban Seiliez. 2010. "Protein and Amino Acid Nutrition and Metabolism in Fish: Current Knowledge and Future Needs.” Aquaculture Research 41(3): 322-32.

xiv. Kawarazuka, Nozomi. 2017. The Contribution of Fish Intake, Aquaculture, and Small-Scale Fisheries to Improving Food and Nutrition Security.

xv. Kemenkes RI. 2013a. "Peraturan Menteri Kesehatan Republik Indonesia Nomor 75 Tahun 2013." Jakarta (TENTANG ANGKA KECUKUPAN GIZI YANG DIANJURKAN BAGI BANGSA INDONESIA): 5-10. http://gizi.depkes.go.id/download/Kebijakan Gizi/PMK 75-2013.pdf.

xvi. ___. 2013b. "Peraturan Menteri Kesehatan Republik Indonesia Nomor 75 Tahun 2013 Tentang Angka Kecukupan Gizi Yang Dianjurkan Bagi Bangsa Indonesia." : 1-10.

xvii. Kementerian Kesehatan RI. 2014. Riskesdas Pedoman Gizi Seimbang.

xviii. Kementrian Kesehatan RI et al. 2019. "IntegratingWASHandNut_WHO_UNICEF_USAID_Nov2015-1.” The Journal of Nutrition 3(3): 607-15. http://dx.doi.org/10.1016/j.jneb.2017.05.059.

xix. Kristinsson, H G, and B A Rasco. 2000. 40 Critical Reviews in Food Science and Nutrition Fish Protein Hydrolysates: Production, Biochemical, and Functional Properties.

xx. Lovell, Tom. 1998. Nutrition and Feeding Fish. Second Edi. Springusiness Media, LLC.

xxi. Mlauzi, M ;Mzengereza K. 2017. “Contribution of Fish Consumption to Reduction of Malnutrition among the Under-Five Children Ini Salima, Malawi." : 1-5.

xxii. Øverby, Nina Cecilie, Sigrunn Hernes, and Margaretha Haugen. 2017. "Effect of Dietary Interventions during Weaning Period on Parental Practice and Lipoproteins and Vitamin D Status in Two-Year-Old Children." Food \& Nutrition Research 61(1): 1350127. https://www.tandfonline.com/doi/full/10.1080/16546628.2017.1350127.

xxiii. Ramakrishnan, Usha, Phuong Nguyen, and Reynaldo Martorell. 2018. "Effects of Micronutrients on Growth of Children under 5 y of Age : Meta-Analyses of Single and Multiple Nutrient Interventions 1 - 3." (January): 191203.

xxiv. Unicef. 2015. “Unicef's Approach to Scaling up Nutrition.” Programme Division: 40. https://www.unicef.org/nutrition/files/Unicef_Nutrition_Strategy.pdf.

xxv. ㄴ-. 2016. "Maternal and Young Child Nutrition Security Initiative in Asia External Evaluation of the EUUNICEF Partnership 2011-2015 Maternal and Young Child Nutrition Security Initiative in Asia." I(April).

xxvi. Unicef South Asia. 2017. "Stop Stunting in South Asia Stop Stunting in South Asia."

xxvii. Unicef, WHO, and World Bank Group. 2017. "Levels and Trends in Child Malnutrition." Joint Child Malnutrition Estimates edition. http://www.who.int/nutgrowthdb/jme_brochoure2017.pdf.

xxviii. WHO. 2014. "WHO | Length/Height-for-Age." WHO.

xxix. Widodo dkk, Slamet dkk. 2015. "Perbaikan Status Gizi Anak Balita Dengan Intervensi Biskuit Berbasis Blondo, Ikan Gabus Dan Beras Merah." Gizi Pangan 10(2): 85-92.

xxx. Widodo, Slamet, Hadi Riyadi, Ikeu Tanziha, and Made Astawan. 2015. "Acceptance Test of Blondo, Snakehead Fish Flour and Brown Rice Flour Based Biscuit Formulation.” International Journal of Sciences: Basic and Applied Research (IJSBAR). 